\title{
THE BREEDING SEASON OF SOME LITTORAL ASCIDIANS IN SCOTTISH WATERS
}

\author{
By R. H. Millar \\ The Marine Station, Millport
}

(Text-fig. I)

In previous papers (Millar, I952; $1954 a$; $1954 b$ ) I have dealt with the reproductive cycle of several ascidians in Scottish waters, and in the present account observations are extended to other species.

The course of breeding was studied in the following species. Family Polyclinidae: Sidnyum turbinatum Savigny, Aplidium nordmanni (Milne Edwards), A. punctum (Giard), A pallidum (Verrill) and Polyclinum aurantium Milne Edwards. Family Didemnidae: Didemnum candidum Savigny and Lissoclinum argyllense Millar. Family Clavelinidae: Clavelina lepadiformis (Müller).

Material was collected at intervals, mostly of $\mathrm{I}-2$ months, throughout the years 1952 and 1953, from the lower part of the shore of the island of Luing, Argyll. At the collecting station Luing and a neighbouring island converge to form a narrow sheltered channel much of which dries at low water of spring tides, and in this area ascidians of several species are abundant.

Breeding condition of each sample was measured by the percentage of specimens having embryos or larvae in the zooids (Families Polyclinidae and Clavelinidae) or in the common test (Family Didemnidae).

Fig. I $(\mathrm{C}-\mathrm{H}, \mathrm{J}, \mathrm{K})$ shows the course of breeding in the eight species just studied. Comparable results for other species previously investigated (Millar, I952; I954 $a$; $1954 b$ ) are also shown graphically (A, B, I, L). All results are plotted on the same time base, although they refer to different years, this procedure being justified, first by the need to get a general picture of breeding, and second by the relatively small year-to-year variations.

A relationship between sea temperature, breeding and geographical distribution in marine animals has been widely recognized, particularly by Appellöf (I912), Orton (1920), Runnström (1927, 1929, I936), and Hutchins (I947). Orton noted that temperature apparently controls the breeding season in many marine animals, and Runnström found experimentally that embryonic development of species occupying the high, middle and low latitudes of the boreal region was possible only at the temperatures prevailing in the corresponding geographical ranges.

The ascidian species of which the breeding period in Scottish waters is now known fall into three geographical groups, as follows: (I) boreo-arctic 
${ }^{\circ} \mathrm{C}$
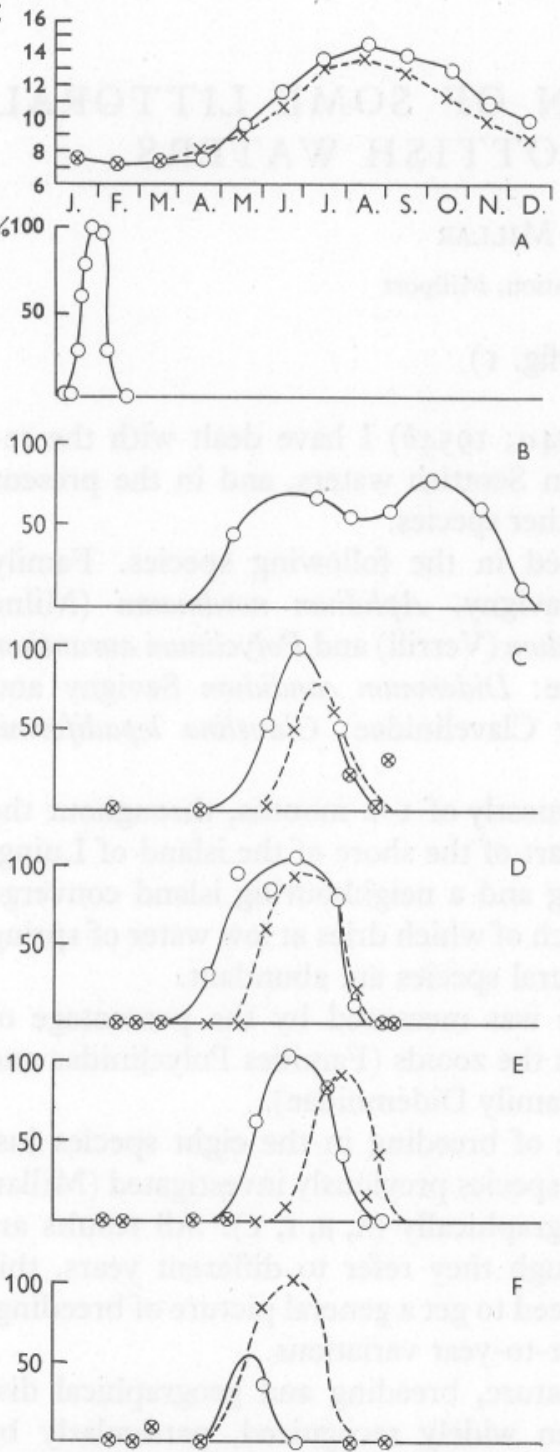

Fig. I. Smoothed curves showing the course of breeding as represented by the percentage of each sample with developing embryos $(\mathrm{O}-\mathrm{O})$ and with larvae $(x-\cdots)$ in the colonial species (C-L). In Pelonaia corrugata (A) the curve shows the percentage of each sample in the process of spawning, as indicated by the condition of the gonad. In Dendrodoa grossularia (B) the curve shows the percentage of each sample with developing embryos or larvae. At the top left corner of the figure is shown the monthly mean sea surface temperature at Millport for the year $1952(\times--\times)$ and $1953(\bigcirc-\bigcirc)$. A, Pelonaia corrugata; B, Dendrodoa grossularia; C, Aplidium pallidum; D, Sidnyum turbinatum; E, Aplidium nordmanni; F, A. punctum; G, Polyclinum aurantium; H, Didemnum candidum; I, Diplosoma listerianum; J, Lissoclinum argyllense; $\mathrm{K}$, Clavelina lepadiformis; L, Botryllus schlosseri.
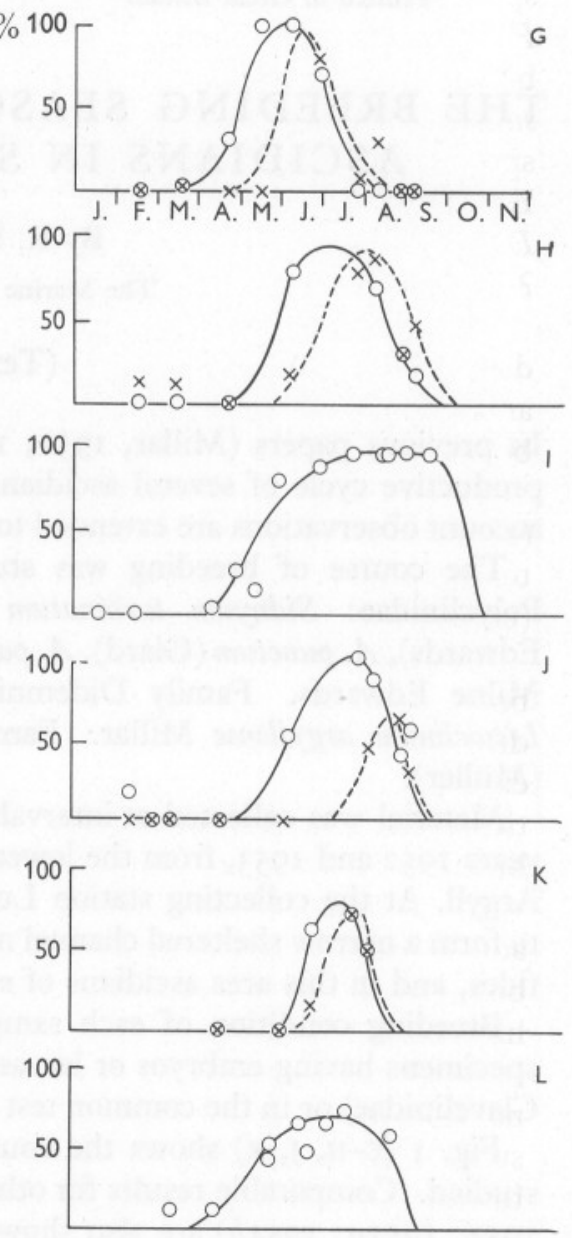
species centred in arctic and extending southwards into boreal waters, e.g. Pelonaia corrugata Forbes and Goodsir; (2) boreo-arctic species centred in boreal and extending northwards into arctic waters, e.g. Dendrodoa grossularia (van Beneden) and ? Aplidium pallidum (Verrill); (3) true boreal species, including Sidnyum turbinatum Savigny, Aplidium nordmanni (Milne Edwards), A. punctum (Giard), Polyclinum aurantium Milne Edwards, Didemnum candidum Savigny, Diplosoma listerianum (Milne Edwards) and ? Lissoclinum argyllense Millar.

The question mark before Aplidium pallidium indicates that its centre of distribution is uncertain, and the one before Lissoclinum argyllense that records are still very scarce. The remaining six of the eight species newly studied are boreal.

It is evident from Fig. I that the breeding periods are of three kinds: (I) short and restricted to the winter (A), (2) long, and extending from spring to late autumn (B), (3) short or moderately long, and restricted to the summer (C-L).

These three groups of species, defined by the time and extent of the breeding season, are the same groups as those defined earlier by geographical distribution. It appears, therefore, that in the species studied the time and extent of the breeding period is related to the centre of geographical distribution of the species. Water temperature is the factor most likely to control the breeding period.

North boreo-arctic species are in British waters near their southern limit, and the short breeding period of Pelonaia corrugata suggests that the southern boundary of species in this group may be fixed by winter temperatures too high for breeding farther south.

Boreal, and especially south boreal, species are in British waters near their northern limit and the short breeding period of several boreal ascidians suggests that the northern boundary is probably fixed by summer temperatures too low for breeding, farther north.

\section{SUMMARY}

The breeding season is given of a number of ascidian species on the Scottish west coast.

The species can be divided into north boreo-arctic, south boreo-arctic, and boreal species, and each of these groups has a characteristic duration and time of breeding season.

\section{REFERENCES}

APPELLÖF, A., I912. Invertebrate bottom fauna of the Norwegian Sea and North Atlantic. In The Depths of the Ocean, by Murray and Hjort. London.

Hutchins, L. W., 1947. The bases for temperature zonation in geographical distribution. Ecol. Monogr., Vol. 17, pp. 325-35. 
MillaR, R. H., I952. The annual growth and reproductive cycle in four ascidians. F. mar. biol. Ass. U.K., Vol. 3I, pp. 4I-6I.

I954 $a$. The annual growth and reproductive cycle of the ascidian Dendrodoa grossularia (van Beneden). F. mar. biol. Ass. U.K., Vol. 33, pp. 33-48.

- $1954 \mathrm{~b}$. The breeding and development of the ascidian Pelonaia corrugata Forbes and Goodsir. F. mar. biol. Ass. U.K., Vol. 33, pp. 68I-7.

Orton, J. H., r920. Sea-temperature, breeding, and distribution in marine animals. F. mar. biol. Ass. U.K., Vol. I2, pp. 339-66.

RUNNSTRÖM, S. 1927. Über die Thermopathie der Fortpflanzung und Entwicklung mariner Tiere in Beziehung zu ihrer geographischen Verbreitung. Bergens Mus. Aarb., 1927, No. 2, 67 pp.

- 1929. Weitere Studien uber die Temperaturanpassung der Fortpflanzung und Entwicklung mariner Tiere. Bergens Mus. Aarb., 1929, No. I0, 46 pp.

1936. Die Anpassung der Fortpflanzung und Entwicklung mariner Tiere und die Temperaturverhältnisse veschiedener Verbreitungsgebiete. Bergens Mus. Aarb., 1936, No. 3, 36 pp. 